\title{
Providing a Technology Edge for Liberal Arts Students
}

\author{
Tracy Chao, Terry Butler, and Peter Ryan \\ University of Alberta, Edmonton, Canada
}

\section{tracy.chao@ualberta.ca terry.butler@ualberta.ca pmryan@ualberta.ca \\ Executive Summary}

Students' employability has long been a challenging issue for many liberal arts colleges and universities. There has been widespread recognition recently that liberal arts students are highly valued as employees. But there is also a public perception that liberal arts students may not be well equipped to face the challenges of employment in the information age. This study is a collaborative effort among three Canadian universities: the University of Alberta, the University of British Columbia, and the University of New Brunswick. At these universities students were surveyed across the liberal arts disciplines, which were defined broadly to include the fields of fine arts, the humanities, and the social science disciplines. (In the remainder of this paper, we use the term "arts" to include all of the liberal arts.) The focus of investigation was the popular perception that arts students "have fallen behind," or are languishing on the wrong side of a "digital divide" with respect to their computer skills, and as a consequence are at a disadvantage when it comes to employment success immediately after graduation.

This research served as the first phase of a two-year project that aims to address the computing skills gap in liberal arts curricula and to provide a technology edge for students' employability. This Technology Edge project will accomplish the following set of goals in three phases:

Phase I: Needs Assessment

- $\quad$ survey the differences in information technology (IT) competencies between $4^{\text {th }}$ year liberal arts and non-arts students

- solicit detailed descriptions of IT competencies from current arts employers

Phase II: Design and Development

- develop learning materials and strategies which address students' IT skill needs

Phase III: Pilot Implementation

- integrate and evaluate IT learning materials and strategies in several arts courses

- accurately measure arts students' IT training during the pilot projects through testing

The last two goals, as listed above, are currently in the process of completion and will be the subject of further development and documentation in this on-going project. This paper summarizes the results from Phase I.

Material published as part of this journal, either on-line or in print, is copyrighted by the publisher of the Journal of Information Technology Education. Permission to make digital or paper copy of part or all of these works for personal or classroom use is granted without fee provided that the copies are not made or distributed for profit or commercial advantage AND that copies 1) bear this notice in full and 2) give the full citation on the first page. It is permissible to abstract these works so long as credit is given. To copy in all other cases or to republish or to post on a server or to redistribute to lists requires specific permission and payment of a fee. Contact Editor@JITE.org to request redistribution permission.
Student surveys and employer focus groups were used to measure the perceived skill level differences in IT competencies between liberal arts and non-arts students at the three institutions mentioned above. As the Canadian university system supports over 580000 students annually (Statistics Canada, 1999), the hope is that this survey will help other Canadian Universities, and in a wider sense all universities, to develop their IT 
educational systems based on the student demand and needs recounted within this report. The smaller samples taken at these universities are meant to be representative of a Canadian perspective as the surveying institutions are strategically located across Canada: the University of Alberta is located on the prairies, the University of British Columbia is a west coast university, and the University of New Brunswick is an east coast university. This survey was conducted from March to October 2002.

From the student surveys, four IT skills (basic computer use, e-mail, word processing, and Internet) were identified as core competency for all students. In other words, all students, arts and non-arts alike, feel that they have a high degree of foundational IT competence. Overall, arts students have a positive attitude to using IT both in the work force and in academia, especially when these skills are in their own specialized area. This attitudinal study goes against the common belief that arts students and technology training do not mix. However, arts students do feel that they are less proficient in their abilities in areas such as presentation, spreadsheet, and database programs.

On the other side of the job market equation, employers now uniformly expect a basic competency with computers. However, employers may articulate this requirement with an emphasis on the standard business suite of software, which includes word processing, spreadsheet, presentation and database skills. This obscures arts students' areas of strengths, and accentuates areas in which they are less adept. Employers are also less confident about arts students' computer skills and expect less from them. Both students and employers strongly prefer to see computer skills integrated into the academic curriculum.

The results generated from this research study will be used for achieving the remaining project goals as the Tech Edge Project continues with the development of instructional material and learning strategies that are focused on arts students' needs and geared to meet employers' expectations.

Keywords: information technology, liberal arts education, computer skills, employability.

\section{Introduction}

There is a widely held view that graduates in liberal arts are at a disadvantage upon first entering the workforce; one of the reasons given is that they lack appropriate information technology (IT) skills. For this study, the liberal arts are generally considered to include those covered by the broadest range of arts disciplines such as fall under the Fine Arts, the Humanities, and the Social Sciences. For example, at the University of Alberta, the arts are broken down shown in Table 1. (In the remainder of this paper, we use the term "arts" to include all of the liberal arts.)

\begin{tabular}{|l|l|l|}
\hline \multicolumn{1}{|c|}{ Fine Arts } & \multicolumn{1}{|c|}{ Humanities } & \multicolumn{1}{c|}{ Social Sciences } \\
\hline Art and Design & Chinese Literature/Language & Anthropology \\
Art History & Classics & Canadian Studies \\
Drama & Economics \\
& Comparative Literature & History \\
& Creative Writing & Linguistics \\
& East Asian Studies & Political Science \\
& English & Psychology \\
& French Language/Literature & Sociology \\
& Film and Media Studies & Women's Studies \\
& Languages & \\
& Philosophy & \\
& Religious Studies & \\
\hline
\end{tabular}

Table 1: The Breakdown of Arts Disciplines at the University of Alberta

Similarly, the Arts Faculties of the University of British Columbia and the University of New Brunswick are arranged under these divisions (University of British Columbia, 2002; University of New Brunswick 2002). 
The perception of an "IT skill deficiency" in the arts is documented in the Canadian National Graduates Survey "Education-Job Skills Match" (Krahn \& Bowlby, 2000). This survey indicated that liberal arts graduates acquired strong writing and communication skills through their university education, but were deficient in "new technology" skills and felt their studies had not contributed greatly in providing them with these critical IT skills. Further, this viewpoint echoes an examination of these issues by Robert Martin and Samuel Fee (2002), who argue that IT skills will increase the employability and competitiveness of liberal arts students. They state:

Coupling the liberal arts graduate's traditional communication skills with IT skills creates a sound foundation for leadership roles in diverse careers (p.41).

This research served as the first phase of a two-year project that aims to address the skill gap in liberal arts curriculum and to provide a technology edge on employability for the students. The Technology Edge project will accomplish the following set of goals in three phases:

Phase I: Needs Assessment

- measure the differences in IT competencies between liberal arts and non-arts graduates

- solicit detailed descriptions of IT competencies from current arts employers

Phase II: Design and Development

- develop learning materials and strategies which address students' IT skill needs

Phase III: Pilot Implementation

- integrate and evaluate IT learning materials and strategies in several arts courses

This paper summarizes the research results from the needs assessment phase of the project, which consisted of a student survey and employer focus groups conducted at three Canadian universities between March and September 2002. Both qualitative and quantitative data were collected in order to draw a complete picture of the IT skills possessed by liberal arts students and the demands upon these skills in their future workplace.

\section{Literature Review on Students' IT Skills and Employability}

Many authors have written about the value of a liberal arts education in the information age. The value of an Arts degree is often associated with an argument about the importance of information literacy as a part of liberal arts training (Breivik \& Jones, 1993; Conroy, 2001; Herman, 2000; Lyman, 1996, 2001; Shapiro \& Hughes, 1996). The vision of liberal arts graduates thriving in the knowledge-based economy is realized by economist Robert Allen's arguments (1999). In his analysis, he makes the case that liberal arts graduates have the intellectual and interpersonal abilities to cope with organizational changes and to solve problems in the rapidly changing environment brought on by the information technology revolution.

Allen first examined the unemployment rates across arts and professional disciplines, as shown in Table 2. The data showed that those graduates of bachelor programs in fine arts, humanities, and, at least for men in the Social Sciences, tend to have a higher unemployment rate than other non-arts areas of study (Fine Arts Men: $6.5 \%$, Women 5.9\%; Humanities Men $6.7 \%$,

\begin{tabular}{|l|c|c|}
\multicolumn{1}{c}{} & Women & Men \\
\hline education & $2.9 \%$ & $3.5 \%$ \\
\hline fine arts & 5.9 & 6.5 \\
\hline humanities & 7.0 & 6.7 \\
\hline social sciences & 3.4 & 5.5 \\
\hline commerce & 4.3 & 4.3 \\
\hline agric/bio & 7.2 & 4.6 \\
\hline engineering & 8.8 & 4.3 \\
\hline nursing & 3.1 & 0.0 \\
\hline other health & 0.6 & 5.7 \\
\hline math/physics & 7.8 & 3.8 \\
\hline
\end{tabular}

Note: excludes people in school in the previous year. "Other" is excluded.

Table 2: Unemployment Rates by field, bachelor degrees, 25 - 29 year olds, 1996 (Source: Allen, 1999, p. 20, Table 2) 
Women $7.0 \%$; Social Sciences Men 5.5\%, Women $3.4 \%$ ). He further compared the percentage of managerial or professional occupation and found that arts graduates were as successful as others in professional fields, as shown in Table 3 (Fine Arts 73\%, Humanities 69.9\%, Social Sciences $70.9 \%$ ). His finding suggests that, contrary to the conventional wisdom that an arts degree does not lead to a good job, there is evidence showing that liberal arts students are successfully employed and well remunerated in the long run. Overall, the discussion around arts students' employability is moving away from "whether or not" arts students are employable to focus on "what" makes them more employable.

The Technology Edge project attempts to tackle the "what" issues in regards to information technology (IT). Specifically, several studies have made an attempt to assess arts students' IT skills. In a recent study (McEuen, 2001), students were found to be well-equipped with basic skills such as word-processing, Internet use, and e-mail, yet lacked the conceptual knowledge of computers and technology. Their attitudes were generally positive and they felt confident in learning technology skills. However, most students claimed that they do not learn IT skills through their academic studies. They learn by trial and error, and rely mostly on peer support, especially those who consider themselves computer shy (Davis, 1999; McEuen, 2001; Selwyn, 1997).

Being early adopters of IT, libraries in many colleges and universities are often involved in surveying students' IT skills, and have become a driving force for promoting information literacy skills on campus (Hepworth, 1999; Snavely \& Cooper, 1997). Libraries' definition of information literacy is very broad, including practical computer skills as well as information management and communication. Their training approaches range from one-time workshops to substantial on-going support (Spitzer, Eisenber \& Lowe, 1998). However, the challenge remains for a discipline-specific integration: how to make IT relevant to the study of literature, history, drama, or political science.

One example of successful integration is given in Anne Agee and Dee Holisky's article "Technology Across the Curriculum at George Mason University" (2000). In this study, Agee and Holisky report on the successful creation of the Technology Across the Curriculum (TAC) Program at George Mason University. In their preliminary research of a need for such a program, Agee and Holisky found that "many businesses want the skills that come with a liberal arts education, provided that these graduates can also handle technology well" (p.6). In other words, this program was required to fulfill the expectations that employers already had of their new employees. After some 200 experiments, they found that the best way to incorporate this program into the curriculum included working directly with the faculty to develop technology components for use in existing courses, as well as separate modules that students would gain credit for upon completion. At present, these courses all include the technology training as a part of their base budget and the shift has only been viewed as positive because of the necessity for this training, not only by students, but by faculty, as well.

As IT permeates the workplace to an ever-greater degree, it changes the way people and organizations think and interact. Basic IT competency is an essential for employability. There is little doubt that IT skills will enhance arts students' employability (Jeffcote, 1997). However, most of the research about students' IT competence has been anecdotal and subjective. The Technology Edge project aims to estab- 
lish current and detailed knowledge about arts students' IT skills and attitudes. Within the broad area of information literacy and computer skill competency, we wished to address some unanswered research questions:

1. A comparison between arts and non-arts students was needed to determine if a digital divide exists -- if so, in what shapes and forms?

2. How well prepared for work are arts students with regards to IT skills -- from both students' and employers' perspectives?

3. Are there differences within the arts population that would suggest ways that appropriate IT training can be tailored to meet the needs of students?

4. What are the best ways to cultivate arts students' IT skills during their academic years?

\section{Methodology}

\section{Student Survey}

After consulting several existing surveys on similar topics, a survey directed at fourth year undergraduate students was devised with the help of the University of Alberta's Population Research Lab to measure students' attitudes and beliefs about their IT competency. Egnatoff's "Computers and Lifelong Learning" (2002) and MacEuan's "How fluent with information technology are our students?" (2001) are specific examples consulted for successful approaches to surveying IT issues. The completed Technology Edge survey was conducted between March and April 2002.

Students were randomly selected to participate in the study. At two of the universities, students were interviewed by telephone. The other university surveyed students face-toface, using the same survey. Numbers of students surveyed are shown in Table 4.

\begin{tabular}{|l|c|c|c|}
\hline Institution & $\begin{array}{c}\text { Arts } \\
\text { Students }\end{array}$ & $\begin{array}{c}\text { Non-Arts } \\
\text { Students }\end{array}$ & Total \\
\hline University of Alberta & 408 & 196 & 604 \\
\hline University of New Brunswick & 125 & 27 & 152 \\
\hline University of British Columbia & 99 & 51 & 150 \\
\hline Totals & 632 & 274 & 906 \\
\hline
\end{tabular}

Table 4: Student Numbers in Three Surveying Institutions

Arts students were sampled at approximately a 1:3 ratio, while non-arts students were sampled at about a 1:20 ratio. This stratified sampling allowed the researchers to examine the differences in various arts disciplines in more detail, yet have a sufficient sample size from the non-arts population to form a comparison base. The arts population includes traditional humanities and liberal arts disciplines, as well as those categorized as social sciences and the performing arts. Non-arts students are defined for the purposes of the survey as those in business, education, engineering, physical education, and science. A screening process was implemented in the beginning of each interview to ensure that only those students who were to graduate in 2002 from a bachelor-level program completed the survey.

Questions in the survey were designed to measure the students' perceptions of their IT skill competencies (an inventory of the actual skills and levels), attitudes toward IT, and preferred ways of acquiring those skills. IT skills were explored under twelve categories:
(1) basic computer skills
(2) electronic communication
(3) word processing
(4) bibliographic programs
(5) databases
(6) spreadsheets

(7) statistical programs

(8) presentations

(9) graphics programs

(10) Internet

(11) web creation

(12) the understanding of how computers work. 
Each category contained 3 to 7 staggered questions to assess students' skill level, which ranged from basic skills to more advanced, or sophisticated, skills pertaining to that category. For example, if students said they knew how to send and receive e-mail, they were then asked if they knew how to use an electronic address book, how to attach a file to a message, and how to configure an e-mail program. The "yes" and "no" answers to these probing questions were then coded into scores on a scale from 0 to 1 (0 being not at all competent and 1 being completely competent).

An attitudinal question was attached to each skill category to assess students' perception of the importance of each skill to their future careers. These results were again recoded to the scale of 0 to 1,0 being negative and 1 being positive. Similarly, the students' opinions of their aptitude for using computers were also surveyed. The general categories for interviewees to discuss their aptitudes were broken down into 1) the enjoyment of working with computers, 2) if they feel comfortable talking about computers with others, 3) if they learn new computer skills easily when being taught in a course, 4) if they feel confident about their ability to master new IT skills on their own, and 5) whether or not they believe that IT skills are useful in advancing their careers.

Other attitudinal questions assessed students' comfort level with IT, self-efficacy, and overall attitude towards IT for their studies and career. It was also important to inquire about students' IT learning experiences at university, and they were asked what they thought were the necessary resources in order to acquire IT skills. These questions will help us design appropriate means of delivery for the IT learning materials in the later phases of the project.

Specifically, there were three open-ended, scenario-based questions to probe students' use of IT in connection with higher-level activities such as evaluation, teamwork, and decision-making. These questions were intended to solicit genuine responses from students concerning their personal approach to the proposed problems. The researchers then looked for patterns of behaviours and how IT activities would be used in these situations. The three scenarios were as follows:

\section{Scenario 1}

Canada's immigration policy has direct impact on Canada's population, economy, and culture. For a course assignment, you are asked to gather information that will reveal our current immigration practice and its impact on our society. How would you gather relevant information for this assignment?

\section{Scenario 2}

For the assignment on Canada's immigration policy, you are working with 3 classmates as a group. As a collaborative effort, you will write a report, including discussion derived from your group work. What means would you use to collaborate and communicate with your classmates?

\section{Scenario 3}

You want to take a university program and you have found that only three universities offer this program. You have one month before making a decision to apply to one of these universities. Suppose you want to choose a university based ONLY on the quality of the program it offers (location, finances, and so on, are not factors). What would you do to make that decision and what materials would you seek as sources of information?

The three-part construction of the survey narrowly defined skills questions, attitude questions, and scenario-based questions. The surveying technique was limited in the sense that students were selfreporting and self-evaluating. Testing of student skills via direct course work was beyond the scope of the first phase of the needs assessment and will only be part of the third phase of this project, which begins in September 2003: Pilot Implementation.

Two types of statistical tests were used for mining the data compiled during the survey. Firstly, an independent group t-test was used to compare the two groups of the arts and non-arts students (the significance of these comparisons are listed throughout the results sections with significance at $<0.05$ ). The 
second test used was the one-way analysis of variance (ANOVA) tests, which were used to compare the three samples from the disciplines of the Fine Arts, the Humanities, and the Social Sciences (again, significance is set $<0.05$ ).

\section{Employer Focus Groups}

Employers who had hired arts students in the past were recruited to participate in this research. These employers, from public, non-profit, and private sectors, came to focus group interviews where questions about their hiring requirements and expectations were discussed. The guiding questions used in the focus groups are listed as follows:

1. When you hire new arts graduates what type of work are you hiring them to do?

2. What is it that your organization values in these new arts graduates? What skills do they have that you want?

3. When people mention IT skills, they can mean many things. What do IT skills mean to you and your organization?

4. When you hire recent university arts graduates, what IT skills do you expect them to have?

5. What IT skills have you found lacking in arts graduates?

6. What suggestions do you have for the university regarding IT skills training for arts students?

Six separate focus groups were conducted. A total of 30 representatives participated: 10 from public, 3 from non-profit and 17 from private organizations. The sessions took place at the University of Alberta and the University of New Brunswick. The qualitative information to be shared herein is part of a larger national study that is being conducted by the University of Victoria via an on-line survey

$<$ http://www.mycoop.ca/ITSsurvey/>. Since this project is still on going, no quantitative figures on a mass scale of the University of Victoria survey will be documented here, other than a notice that the preliminary results support the interpretations garnered from the limited pool of information gathered thus far.

\section{Results}

\section{Student Survey}

\section{Skill inventory}

The data (see Table 5) reveals that arts students, like their non-arts colleagues, believe they are very competent in four of the twelve skill categories ( 0 being not at all competent and 1 being completely competent). These skills are basic computer tasks, electronic communication, word processing and Internet. These four skill categories are labeled as "generic skills" in this paper because of their high mean scores from all students. Table 5 also indicates the skill categories that have statistical significance of difference for the two populations being compared. Arts students show a lower level of faith in eight of the skills categories with a statistically significant difference existing in 7 of these cases.

\section{IT in higher level abilities}

The scenario questions, designed to probe students' use of IT in the processes of information gathering, teamwork, and decision-making, confirmed that the large majority of students (arts and non-arts) feel comfortable using IT approaches, and often prefer them to alternatives.

On the question of information gathering (as is described above in Methodology: Scenario 1), students adopt a variety of approaches and IT was often the preferred means. The Internet (or the WWW) is for them the dominant channel for seeking information: $68.8 \%$ of students state that they would use the Internet as their primary source. Library activities were also mentioned frequently: $37 \%$ of the students 


\begin{tabular}{|c|c|c|c|}
\hline \multirow[b]{2}{*}{ Perceived skill level } & \multicolumn{2}{|c|}{$n=906$} & \multirow[b]{2}{*}{ Sig. } \\
\hline & $\begin{array}{c}\text { Arts } \\
\text { (mean) }\end{array}$ & $\begin{array}{c}\text { Non-Arts } \\
\text { (mean) }\end{array}$ & \\
\hline Basic computer tasks & .99 & 1.00 & \\
\hline E-communication & 1.00 & 1.00 & \\
\hline Word Processing & 1.00 & 1.00 & \\
\hline Bibliographic program & .23 & .25 & \\
\hline Spreadsheet program & .84 & .98 & $*$ \\
\hline Database program & .56 & .74 & $*$ \\
\hline Statistical program & .55 & .65 & $*$ \\
\hline Presentation program & .67 & .88 & $*$ \\
\hline Graphics or illustration programs & .54 & .67 & $*$ \\
\hline Internet & 1.00 & 1.00 & \\
\hline Web site creation & .34 & .62 & $*$ \\
\hline Understanding of how computers work & .79 & .89 & $*$ \\
\hline
\end{tabular}

Table 5: Summary of Students' IT Skill by Faculty

$(\mathrm{p}<0.05, *=$ statistical significance)

quoted using library resources. Within the library resources, students cite databases, online catalogues, or indices as a means to find information. Some students proposed using surveys or interviews to gather first-hand information (4.3\%). Overall, both IT and non-IT methods were mentioned as a preferred means for searching information, with a very high percentage of students relying on the Internet and digital resources within a library context. A typical representative comment from this sample states: "Well I would probably go on-line and try to look at some Government of Canada websites. I suppose I would go to the library and I would typically look for journals and use their on-line catalogues etc."

In terms of the use of IT in collaborative endeavours (Scenario 2), e-mail was the only IT tool students used frequently (82\%). Only a very small percentage of students said they would use synchronous chat tools such as MSN Messenger or ICQ (13\%) for a class project. They proposed to use e-mail to make appointments, to brainstorm ideas, or to share files with one another. The majority of students reported they would rely on face-to-face meetings or telephone contact (44.8\%). Asynchronous tools such as discussion boards were not commonly mentioned, except for a few students who have been exposed to this tool through a course they have taken, or if a student lived far from campus.

A high percentage of students (72\%) said they would visit university web sites when choosing an academic program (Scenario 3). Some would judge the quality of a program (or a university) by the quality of the web site and information presented on it. Most students would use university web sites to find contact information, for example e-mail address or telephone number, and pursue their inquiry with direct contact with the personnel at the institution. In contrast to the responses on the first scenario, students would rely more on first-hand experiences ("visit the school"), personal referral (ask professors, counsellor, students, alumni or family and friends), and third party evaluation (MacLean's magazine survey). Students were aware of the difficulty of filtering and assessing online information. One student notes, "for very important information I like to talk directly." A few students commented that they would look at not only the course listings but also the course materials and class size. It is obvious that more non-IT approaches would be utilised by students in this type of decision-making.

\section{Attitudes}

Overall, arts students valued IT skills as important for their career in varying degrees, as shown in Table 6 ( 0 being negative; 1 being positive). The four generic skills categories (basic computer tasks .95 , elec- 


\begin{tabular}{|l|c|c|c|}
\multicolumn{1}{c}{} & \multicolumn{4}{c|}{$\mathbf{n = 9 0 6}$} \\
\cline { 2 - 4 } \multicolumn{1}{c|}{ Perceived Importance (Attitude) } & $\begin{array}{c}\text { Arts } \\
\text { (mean) }\end{array}$ & $\begin{array}{c}\text { Non-Arts } \\
\text { (mean) }\end{array}$ & Sig. \\
\hline Basic computer tasks & .95 & .97 & \\
\hline Electronic communication & .94 & .97 & \\
\hline Word processing & .97 & .97 & \\
\hline Bibliographic program & .48 & .40 & $*$ \\
\hline Spreadsheet & .70 & .87 & $*$ \\
\hline Database & .57 & .70 & $*$ \\
\hline Statistical program & .54 & .66 & $*$ \\
\hline Presentation program & .84 & .90 & $*$ \\
\hline Graphics or illustration programs & .57 & .64 & $*$ \\
\hline Internet & .96 & .95 & \\
\hline Web site creation & .38 & .29 & $*$ \\
\hline Understanding of how computers work & .59 & .67 & $*$ \\
\hline
\end{tabular}

Table 6: Perceived Importance of IT Skills for Career (arts/ non-arts)

Range 0 to 1 : 0 being negative, 1 being positive

$(\mathrm{p}<0.05, *=$ statistical significance $)$

tronic communication .94, word processing .97, and Internet .96) registered higher on the list than the other categories.

Interestingly, bibliographic and presentation programs are two skill areas that have lower means on the skill measure for arts students (.23 and .67 respectively) but higher means on the attitudinal measure (.48 and .84 respectively). Database, statistical programs, graphics programs, and web site creation demo nstrate a similar trend but the difference is minimal. The reverse trend is found in spreadsheet skills and the understanding of how computers work, where arts students score .84 and .79 respectively on the skill measure and .70 and .59 on the attitudinal measure.

Attitudes toward specialized skill sets exhibit significant difference between arts and non-arts populations. Particularly, arts students value bibliographic program and web creation skills (.48 and .38) more than non-arts students do (.40 and .29), while there were significantly less arts students who thought spreadsheet, database, statistical program, presentation program, graphics programs, and understanding how computers work were important for their career.

\begin{tabular}{|l|c|c|c|}
\multicolumn{1}{c}{ Student Aptitude } & Arts & Non-Arts & Sig. \\
\cline { 2 - 4 } \multicolumn{1}{l|}{} & & & \\
\hline Enjoy working with computers & .88 & .95 & $*$ \\
\hline Feel comfortable talking about computers with others & .87 & .79 & $*$ \\
\hline Learn new computer skills easily & .89 & .97 & $*$ \\
\hline Feel confident to master IT skills & .96 & .98 & \\
\hline IT skills are useful in advancing one's career & .94 & .98 & $*$ \\
\hline
\end{tabular}

Table 7: Students' Aptitude with IT (arts/ non-arts)

$(\mathrm{p}<0.05, *=$ statistical significance $)$ 
Arts students' aptitude and comfort with IT (see Table 7) was significantly lower than non-arts students', when asked about their attitude to using computers, their ease of learning new skills, and the importance of these skills for one's career. An interesting highlight from the aptitude survey is that the arts students feel more comfortable talking about computers with others, and there is no significant difference on the measure of students' confidence of mastering IT.

\section{IT learning experiences and resources}

When questioned about current methods of acquiring IT skills, arts students and non-arts students did not demonstrate any vast differences in their responses. One difference, however, lies in the contrast between "current methods" and "preferred methods" of acquiring IT skills. A majority of all students said they learned about computers by asking people informally, or by trial and error on their own. Table 8 shows that the students' preferred methods for learning were through course study or work experience that would allow them to learn IT. With respect to in-class exposure to IT, $62.6 \%$ of arts students said that they acquired IT skills in their University courses, while $70.4 \%$ of non-arts students reported the same.

\begin{tabular}{|l|c|c|}
\hline Student Methods & $\begin{array}{c}\text { Current } \\
\text { methods }\end{array}$ & $\begin{array}{c}\text { Preferred } \\
\text { methods }\end{array}$ \\
\hline Through courses & 3 & 1 \\
\hline Informally ask others & 1 & 3 \\
\hline Work experience & 4 & 2 \\
\hline On one's own & 2 & 4 \\
\hline
\end{tabular}

Table 8: Ranking of Methods of Acquiring IT Skills.

Furthermore, students strongly preferred to acquire IT skills through credited training in the form of workshops, one-on-one support, and course-related, assignment-driven learning. They also preferred practical experiences such as co-op programs that would give them hands-on experience. Both arts and non-arts students believed that these skill sets should start to be acquired in the first year of university.

Over $93 \%$ of students from other disciplines thought IT should be part of the academic curriculum, while only $82 \%$ of arts students thought the same. As listed in the Methodology section, these other disciplines include business, education, engineering, physical education, and science. The majority of arts students $(71 \%)$ felt that the academic program did not provide the IT skills they need for the workplace, and about the same proportion $(69 \%)$ of non-arts students felt the same way.

In terms of preparedness for work, $85 \%$ of arts students thought that they have sufficient IT skills entering the workplace, while $98 \%$ of non-arts students felt that way.

\section{Within arts comparisons}

As presented in the methodology, arts students' populations are divided into three disciplinary groups: fine arts, humanities and social sciences. Table 9 shows that social science students perceived the mselves having higher skill levels in spreadsheet (Fine Arts .73, Huma nities .82, Social Sciences .86), database (Fine Arts .43, Humanities .50, Social Sciences .60), and statistical programs (Fine Arts .29, Humanities .40, Social Sciences .64). Fine arts students perceived themselves having higher skill level in graphics programs (Fine Arts .70, Humanities. 62, Social Science .49). 
$\mathrm{n}=632$

\begin{tabular}{|l|c|c|c|c|}
\cline { 2 - 5 } \multicolumn{1}{c|}{ Perceived skill level } & $\begin{array}{c}\text { Fine Arts } \\
\text { (mean) }\end{array}$ & $\begin{array}{c}\text { Humanities } \\
\text { (mean) }\end{array}$ & $\begin{array}{c}\text { Social Sciences } \\
(\text { mean })\end{array}$ & Sig. \\
\hline Basic computer tasks & 1.00 & .98 & .99 & \\
\hline E-communication & 1.00 & .99 & 1.00 & \\
\hline Word Processing & 1.00 & 1.00 & .99 & \\
\hline Bibliographic program & .21 & .21 & .25 & \\
\hline Spreadsheet program & .73 & .82 & .86 & $*$ \\
\hline Database program & .43 & .50 & .60 & $*$ \\
\hline Statistical program & .29 & .40 & .64 & $*$ \\
\hline Presentation program & .65 & .62 & .68 & \\
\hline Graphics or illustration programs & .70 & .62 & .49 & $*$ \\
\hline Internet & 1.00 & .99 & 1.00 & \\
\hline Web site creation & .40 & .40 & .31 & \\
\hline Understanding of how computers work & .84 & .80 & .78 & \\
\hline
\end{tabular}

Table 9: Skill Comparisons Among Three Disciplines

( $\mathrm{p}<0.05, *=$ statistical significance)

On the attitudinal measures (Table 10), humanities students were less convinced of the importance of IT tasks compared with the other two groups of arts students. Social science students highly value the datarelated areas such as bibliographic (Fine Arts .37, Humanities .43, Social Sciences .51), spreadsheet (Fine Arts .43, Humanities .60, Social Sciences .76), database (Fine Arts .30, Humanities .46, Social Sciences .64), and statistical programs (Fine Arts .19, Humanities .35, Social Sciences .65). Fine arts students consider graphics programs to be very important (Fine Arts .79, Humanities .51, Social Sciences .55).

\begin{tabular}{|l|c|c|c|c|}
\multicolumn{1}{c}{ Perceived Importance (Attitude) } & $\begin{array}{c}\text { Fine Arts } \\
\text { (mean) }\end{array}$ & $\begin{array}{c}\text { Humanities } \\
(\mathbf{m e a n})\end{array}$ & $\begin{array}{c}\text { Social Sciences } \\
(\mathbf{m e a n})\end{array}$ & Sig. \\
\hline Basic computer tasks & .95 & .91 & .97 & $*$ \\
\hline E-communication & .95 & .91 & .95 & \\
\hline Word Processing & .97 & .95 & .98 & \\
\hline Bibliographic program & .37 & .43 & .51 & $*$ \\
\hline Spreadsheet program & .43 & .60 & .76 & $*$ \\
\hline Database program & .30 & .46 & .64 & $*$ \\
\hline Statistical program & .19 & .35 & .65 & $*$ \\
\hline Presentation program & .81 & .79 & .85 & \\
\hline Graphics or illustration programs & .79 & .51 & .55 & $*$ \\
\hline Internet & .94 & .97 & .96 & \\
\hline Web site creation & .46 & .44 & .35 & \\
\hline Understanding of how computers & .67 & .58 & .59 & \\
work & & & & \\
\hline
\end{tabular}

Table 10: Attitude Comparison Among Three Disciplines $(\mathrm{p}<0.05, *=$ statistical significance) 


\section{Employer Focus Group}

All participants stressed the importance of "skills" rather than the possession of a degree. Employers hire an employee based on the skills required for a job. Often employers do not care how those skills are acquired, as long as the student can demonstrate that he or she possesses them. For many organizations, an arts degree alone was not sufficient qualification for entry-level employment. A lack of computer skills, and the lack of the employer's required skills found within students' academic specializations, were among the barriers reported.

In other words, employers argued that arts students must demonstrate experiences relevant to the job or industry. Since the arts degree is seen as a base upon which specialization is built, some organizations said that they hire arts graduates because of their strengths in communication skills, and then train them on the job. This is especially true of all large private and public sector employers. One participant stated, "It is important to have somebody who has good communication skills and I find arts graduates tend to have that ...they also have good listening skills." This positive view of arts graduates was generally shared by all of the focus group participants. In addition, employers value arts students' interpersonal, teamwork, and critical thinking skills; and their openness and willingness to learn.

Overall, employers stated that a basic knowledge of computer skills was essential. For the employers, these skills included the following set of industry standards:

- Microsoft Office suite (word processing, spreadsheet and presentation)

- Windows environment

- Opening and closing programs

- Storing files and navigating directories

- Internet (web browsing)

- E-mail

This interviewee's comments were typical: "I think that they need to know how to use Office Suite and at least know how to do Power Point presentations. I don't know if they're doing that now. Certainly, some of the students in our interviews didn't know Access or other Microsoft products." Every employer agreed that these basic skills are now expected. One stated, "If some candidates had no proficiency with the computer ... proficiency means having the fundamentals... they won't be looked at twice."

About half of the employers recognized the need for more advanced IT skills, based on different job requirement. However, these employers also said that it might not be necessary for students to have indepth knowledge of a particular software program, since technology changes constantly. Employers expect their potential employees to have the ability and desire to learn new IT skills continuously. One participant even said that basic IT skills are as important to a graduate today as reading and writing were thirty years ago. Another participant pointed out a crucial job market trend: if an organization receives many applications for a job, then they can afford to be selective. Applicants with IT skills will have an advantage even though other applicants meet the job qualification. One participant observed "students coming out of university who don't have these skills are going to the technical colleges to pick them up before they apply for jobs because they realize they don't have the basic skills to get that position."

A divergence of opinion existed between employers about arts graduates' IT skills upon entering the work force. Some public-sector participants said they see arts graduates coming out with few gaps in general IT skills. But it was noted that these students lack a conceptual understanding of computers and experience with data-oriented programs. Some participants from the private sector agreed but took a much more critical view. They stated that arts graduates did not have the expected basic IT skills, such as how to maintain files and make back-ups, how to enter data, or even basic keyboarding. They thought that learning IT skills informally on their own or through friends was not an adequate solution. One said, 
"[if] you are self-taught, you end up picking up some bad habits. So maybe you are not doing it in the best way, the most efficient way."

Overall, the majority of the employers $(85 \%)$ were in consensus: arts students do need to improve their IT skills. "If there was one discipline with an IT gap, it would be arts graduates," one employer explained and went on saying that "the other degrees have serious advantages with respect to IT. Arts students do have a disadvantage because they are not obligated to have certain software skills."

Employers reiterated that those students who already possess IT skills should gain more, and better, skills to prepare them for the work force because this would offer them an advantage over others applying for a specific job. However, many employers also stated that people with IT skills were not necessarily valued over others. Instead, a person with the job qualifications and a knowledge of IT, or a willingness to participate in life long-learning, were valued over others with only particular IT skills, but not the desired attitude. A positive attitude to life-long learning is important for employers, who like to keep quality employees and continue to train them, especially when many companies have proprietary computer systems that must be learned in-house. As much as the employers stress the importance of learning IT skills in the university, they also said that students would be required to continue to upgrade their skills on the job, either on their own time or through in-house training. This varied even within individual companies.

Participants were split on the issue of training methods. Private sector participants put an emphasis on mandatory courses and competency testing. They thought IT testing should be required. Public and nonprofit sector participants said self-training is crucial; particularly, because these sectors often do not have additional funds to train employees. But all employers agreed that using IT skills in academic classes would add value to a student's skill set. For instance, a Bachelor of Arts student whose major field of study is history should know how to use Graphical Information Systems (GIS) in relation to historical maps and data. Gaining these IT skills while doing course work was seen as the best way to do this. Distance and e-learning were suggested as alternative modes to deliver IT skill training.

Curriculum using technology in case studies was suggested, as more likely to be effective than a core curriculum with piecemeal add-ons, where the student is given no credit for acquisition of these skills. One focus group participant suggested that degree programs must incorporate this type of learning:

[Integration] is the ideal way of teaching those skills and teaching the application of them, rather than them have this separate silence [learning in isolation].

Employers agreed that students need recognition of these IT skills during their academic program. The importance of assessment of a student's IT knowledge was also raised.

\section{Discussion}

The needs assessment results form an interesting picture concerning student perceptions of their IT skills upon graduation from these three universities and provide us with valuable data for comparison by interpreting the results of the survey. The following analysis and discussion makes use of these research results and aimed to answer the four research questions that were posed at the beginning of this report.

\section{Does a digital divide exist between arts and non-arts students? If so, in what shapes and forms?}

As shown in Table 5, four skill sets - basic computer tasks, electronic communication, word-processing, and Internet skills- emerged from the survey as generic skills. Arts and non-arts students alike said that they possess these skills. The notion of a digital divide or of a disadvantage for arts students at this level is inaccurate. An actual testing of students' skills, as will be conducted in the third phase of this project, is required to offer further evidence of this phenomenon. However, student demand for IT skills is a very important factor in creating university courses that meet students' career and academic needs. 
Providing a Technology Edge for Liberal Arts Students

A more nuanced notion is appropriate to describe the situation than that of a digital divide. Seven of the twelve skill sets showed statistical significance between the arts and non-arts populations, with arts students scoring lower in every. These results show that arts students do feel that they have comparable generic IT skills, but are behind non-arts students beyond this basic skill set.

Table 6 shows arts students recognized the importance of competence with presentation software (arts .90 , non-arts .84). This corresponds with the employers' perspective: presentation is a very important skill that students must have. Arts students themselves see room for improvement in this category, as their score of attitudinal measure is higher than that of perceived skill level.

Spreadsheet skills are another must-have that employers stress. Arts students do not feel they have experience or a high level of ability here (especially those students outside the social science area), nor do arts students believe as strongly as the non-arts students that spreadsheet skills will be important for them in employment. Database skills show the same pattern: arts students feel they are not as strong as non-arts students, yet employers consider these skills to be fundamental.

These three areas alone can contribute to a disconnection between arts students' abilities and employers' expectations. Faced with the classic question, "Are you familiar with computers: word processing, spreadsheet, and database programs?" (couched in the Microsoft-specific terminology of "Word, Excel, and Access"), arts students may be forced to react defensively, since this deficiency is viewed to exist. In other words, a perception of digital divide may arise because of arts students' deficiency in these skill areas but their general IT competency may go unnoticed and unexplored.

The digital divide also exists on the attitudinal measures between arts and non-arts students. Unlike the skill inventory where arts students' scores were always lower than non-arts students' scores (and 7 of the twelve categories show statistical significance), two items on the attitudinal measures stand out as being much more highly valued by arts students: bibliographic program (arts .48, non-arts .40) and web creation (arts .38, non-arts .29). This indicates student need and motivation to acquire these skills.

Although there were significant differences found in the skills inventory and students' attitudes toward IT, there was no difference in arts and non-arts students' use of IT in the higher-level tasks such as information gathering, collaboration, and decision-making, if these skills are incorporated into the students' specializations. Employers need to be told that for the higher-level, integrative activities, which they value, arts students are just as willing and as able as the general graduating population. It is also important to note that arts students are equally confident that they will master a new IT skill that is presented to them (arts .96, non-arts .98: Table 7).

These statistics are interesting given that both arts and non-arts students said that they are currently gaining skills either on their own or by asking others as their primary means and NOT by learning them in class, as shown in Table 8. Perhaps it is the case that these figures are pointing to an over-all deficiency in university education. However, at this time, this question is beyond the scope of the project's investigation.

2. How well prepared for work are arts students with regards to IT skills from both students and employers' perspectives?

Arts students are quite confident (.85) that they have sufficient IT skills entering the workplace, but are not as confident as their non-arts counterparts (.98). This may be due to their more critical assessment of their skill levels.

On one hand, arts students value IT skills and think it should be part of the curriculum, as related during the three open-ended scenario questions. On the other hand, their feeling on this matter was not as strong as non-arts students. This may be a result of the perceived connection between the discipline and IT. Does a historian need to be technology savvy? Will IT be of value to an English major? They think of 
the value of IT in general but may have difficulty in conceptualizing such value in concrete terms with regards to a job or a career path. More vocationally-directed programs, and those where computer practice is embedded in the curriculum, make this linkage clearer for students.

Our research identifies that employers are carrying a misconception about arts students' preparedness for work. The notion that arts students generally are unprepared for work with respect to their IT skills, or that they are less well prepared than their non-arts counterparts, is incorrect. With respect to the four core skill sets, which we have called generic IT skills, all students believe they are highly competent. There is a disconnection between the skill sets that some employers consider "basic" and those that arts students will typically acquire to this point. Therefore, infusing IT skills more broadly into the arts curriculum will have its own benefits, but this in itself will not address these employability issues. It suggests that a better strategy for preparing arts students for work will be to create specific IT skills activities that provide the skill sets that employers generally expect and want.

This analysis suggests that arts students should be provided with opportunities to improve in some skill categories, especially spreadsheet, presentation, and database programs, as well as conceptual understanding of IT. Another issue to be addressed is arts students' confidence to present their skills appropriately. The employers stress that it is the skill sets that count when they make decision about hiring. Traditionally, the arts degree emphasizes subject area expertise, and does not highlight skill sets. Also, arts students do not perceive a strong connection between the world of technology and their discipline.

\section{Are there differences within the arts population that must be addressed through tailoring IT training to meet the needs of students?}

The results from the discipline comparison within the arts population suggest that IT skills vary, and the learning needs of these students should be addressed in various ways. Specific skills reside quite naturally in different disciplines, so that training must be focused where it is most needed. This will be important for integrating training materials into a classroom context, as each course will require tailor made IT training.

\section{What are the best ways to cultivate arts students IT skills during their academic years?}

The majority of the students learned IT informally or on their own. Non-arts students developed more IT skills, and they had more exposure to IT during their studies. Our statistics confirmed this: $58 \%$ of arts students and $68 \%$ of non-arts students reported using IT in their courses. Although we did not know how much exposure students may have outside their studies, nor in detail how IT was used in those courses, we can speculate that IT in academic courses provided students with the opportunity to learn even though they often had to resort to informal and self-directed learning. Students expressed a preference for credited training.

Employers are also strong advocates for formal inclusion of IT training into the academic program. Formal recognition helps students and employers identify the skill sets that students possess. This is a key point that arises from this research: no matter what IT skills are incorporated into arts curriculum, and how the IT training is implemented, there needs to be some form of formal recognition in place.

However, students do feel comfortable learning from their peers in informal settings. This is a cultural phenomenon and it should be optimized when implementing an IT training strategy. It will be a challenge to blend the informal learning and support culture into the formal IT training students receive as part of a course.

Students suggest that learning IT through their course assignments is effective, and employers' responses also call for IT integration in the discipline. The challenge, however, is the competing demands on the curriculum. Is there any room to include IT learning outcomes in a course that is already pressed for time? There is a need for consideration of flexible delivery mechanisms and innovative means of in- 
tegration. This is the goal for the $3^{\text {rd }}$ phase of the project and the researchers will report the pilot implementation when the project concludes in 2004.

\section{Conclusion}

The term "digital divide" is not very useful to describe the pattern of similarities and differences between arts and non-arts students, with respect to their IT skills and attitudes. Such a simple dichotomous description is misleading, and unhelpful towards improving the employability situation. We must start by recognizing that arts students do perceive themselves with high competence in the generic IT skill categories. The areas of their weakness can be targeted through various learning strategies.

The concern that this emphasis on IT skills will turn university education into vocational skill training can be promptly addressed. All the students surveyed have acquired a set of computer skills, primarily by indirect means and not at the expense of their academic programs. Non-arts students have been more successful at this, and are taking programs that integrate computer activities to an increasing extent. IT skills which are sharpened and exercised in connection with academic study will be more valuable to the student, and to an employer, than those acquired out of context and peripherally. All disciplines in arts can provide opportunities for students to complete their scholarly work at the same time as they acquire and expand their repertoire of computer skills. The purpose of the Technology Edge project is to augment the repertoire of IT skills that arts students acquire as they complete their first degree. There is an excellent chance to improve arts students' employability by giving them additional selected IT skills. The next phase of the Technology Edge project will develop and pilot various learning materials and approaches to achieve this goal.

\section{Acknowledgements}

The Tech Edge Project Team for the first phase included the following contributors from the partner institutions: Anne Higgins and Penny Short, University of New Brunswick; Margaret Wicken, Orion Marketing Research; and Ulrich Rauch and Emiela Kaufman, University of British Columbia. And special thanks to Harvey Krahn, University of Alberta for his assistance on the data analysis.

\section{References}

Agee, A. S., \& Holisky, D. A. (2000). Technology across the curriculum at George Mason University. EDUCAUSE Quarterly, 4, 6-12.

Allen, R.C. (1999). Education and technological revolutions: The role of the social sciences and the humanities in the knowledge based economy. Vancouver, B.C. Available online at http://www.sfu.ca/ wwwdoa/allen99.pdf

Breivik, P.S., \& Jones, D.L. (1993). Information literacy: Liberal education or the information age. Liberal Education, 79 (1), 6.

Conroy, F. (2001). In a technocratic age, study of the liberal arts is even more important. Christian Science Monitor, 93, 163.

Dain, J. (1991). Women and computing: Some responses to falling numbers in higher education. Women's Studies International Forum, 14, 217-225.

Davis, P. (1999). How undergraduates learn computer skills: Results of a survey and focus group. Technology Horizons in Education (THE) Journal, 26 (9), 68-71. Available online at http://www.thejournal.com/magazine/vault/A2063.cfm

Durndell, A., Glissov, P., \& Siann, G. (1995). Gender and computing: Persisting differences. Educational Research, 37 (3), 219-227.

Egnatoff, W. (n.d) Computers and Lifelong Learning. On-line Survey. January $15^{\text {th }}, 2002$. http://educ.queensu.ca/ cll/

Hepworth, M. (1999) A study of undergraduate information literacy and skills: The inclusion of information literacy and skills in the undergraduate curriculum. 65th IFLA Council and General Conference (Bangkok, Thailand, August 20 28). Available online at http://www.ifla.org/IV/ifla65/papers/107-124e.htm

Herman, R.E. (2000). Liberal arts the key to the future. USA Today, 129 (26), 34-41. 
Jeffcote, R. (1997). Vocational computing skills and social science students - Do they mix? Some evidence from an interdisciplinary degree programme. Journal of Vocational Education and Training, 49 (2), 253-265.

Krahn, H., \& Bowlby, J.W. (2000). Education-job skills match: An analysis of the 1990 and 1995 National Graduates Surveys. Hull, Quebec: Applied Research Branch, Human Resources Development Canada.

Lyman, P. (1996). Technology and computer literacy. In N. H. Farnham \& A. Yarmolinksy (Eds.), Rethinking Liberal Education (pp. 109-123). New York: Oxford University Press.

Lyman, P. (2001). Information literacy. Liberal Education, 87 (1), 28-37.

Martin, R.E., \& Fee, S.B. (2002). IT for the liberal arts college: A window of opportunity. EDUCAUSE Quarterly, 1, 39-42.

McEuen, S.F. (2001). How fluent with information technology are our students? EDUCAUSE Quarterly, 4, 8-17.

Selwyn, N. (1997). Teaching information technology to the "computer shy": A theoretical perspective on a practical problem. Journal of Vocational Education and Training, 49 (3), 395-408.

Shapiro, J.J., \& Hughes, S.K. (1996). Information literacy as a liberal art: Enlightenment proposals for a new curriculum. EDUCOM Review, 31 (2). Available online at http://www.educause.edu/pub/er/review/reviewArticles/31231.html

Shashaani, L. (1995). Gender-based differences in attitudes towards computers. Computers and Education, 20, 169-181.

Snavely, L., \& Cooper, N. (1997). Competing agendas in higher education: Finding a place for information literacy. Reference and User Services Quarterly, 37 (1), 53-62.

Spitzer, K.L., Eisenber, M.B., \& Lowe, C.A. (1998). Information literacy: Essential skills for the information age. Syracuse University: ERIC.

Statistics Canada. (1999). University enrolment full-time and part-time. Government of Canada. Available online at http://www.statcan.ca/english/Pgdb/educ03a.htm

University of British Columbia. (2002). Faculty of Arts Home Page. Available online at http://www.arts.ubc.ca/FOA/foa.cfm?page=Units\&v1=Departments\&v2=Schools

University of New Brunswick. (2002). Faculty of Arts Home Page. Available online at http://www.unbf.ca/arts/

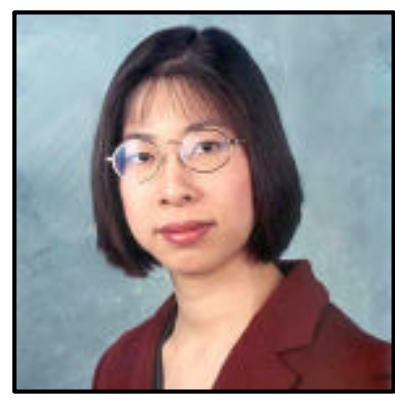

Tracy Chao holds a MA in Educational Technology and is the lead instructional designer for the Technology Edge Project. She specializes in needs assessment, instructional design and educational evaluation. She works with faculty members in technology integration projects and facilitates pedagogical changes in arts curriculum. Her research interests lie in the discipline-specific application of educational technology.

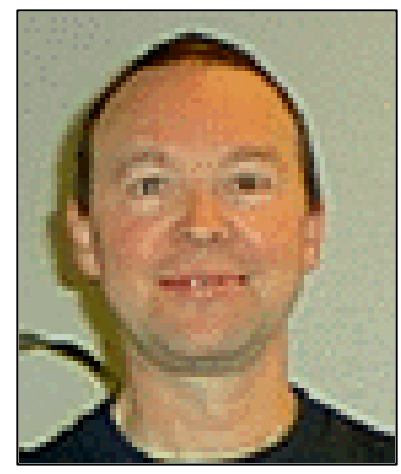

Terry Butler is the Director of the Faculty of Arts Technologies for Learning Centre at the University of Alberta. The centre supports all Arts teaching staff as they explore the potential of IT and adopt new methods of teaching in their disciplines. He is also the Humanities Computing Coordinator for the Faculty, and is responsible for securing an appropriate technology infrastructure for teaching and research in the Humanities. 


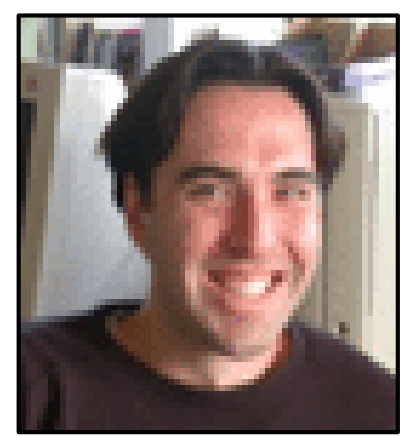

Peter Ryan is the Project Coordinator for the Tech Edge Project Team. He completed his Master of Arts in Humanities Computing, specializing in English at the University of Alberta. His current thesis project is entitled "Progress: the Consensus of Meaning in Modelling the Semantic Web". His research interests include IT standardization bodies and the use of IT in teaching. In the fall of 2003, he begins his doctoral studies in Communication and Culture at Ryerson University in Toronto, Ontario. 